\title{
On the Sound Financial Valuation of Flexibility in Information Systems
}

\author{
Christoph Sebastian Dorsch
}

Received: 18 May 2012/ Accepted: 26 May 2014/Published online: 3 March 2015

(C) Springer Fachmedien Wiesbaden 2015

\begin{abstract}
Flexibility often represents the key area of value added by investing into an information system (IS) but also carries significant costs. Therefore, its quantitative financial valuation is of vital importance to make economically informed decisions about flexibility. This is challenging due to varying flexibility definitions and the complexity of the flexibility construct in itself. To address this challenge, this paper analyzes the scientific literature concerned with the financial valuation of flexibility in information systems (FIS). In the first part, it introduces fundamental requirements for a proper financial valuation, discusses the characteristics of FIS that are driving its economic value and identifies suitable financial valuation approaches. In the second part, a structured review of literature focusing on the application of FIS valuation analyzes to what extend the existing literature supports economically informed decisions within flexibility design. Further research is indicated with regard to dependencies between flexibility and the existing IS landscape as well as to a more structured and comprehensive approach to examine all interacting features of an IS enabling flexibility in the first place. In summary, joining the theoretical basis and the application of FIS valuation, this paper gathers all necessary fundamentals for a sound financial valuation of FIS and reveals the need for further development within this stream of BISE research.
\end{abstract}

Electronic supplementary material The online version of this article (doi:10.1007/s12599-015-0371-7) contains supplementary material, which is available to authorized users.

C. S. Dorsch $(\square)$

FIM Research Center Finance \& Information Management, Augsburg University, Universitaetsstr. 12, 86159 Augsburg, Germany

e-mail: christoph.dorsch@fim-rc.de
Keywords Change - Decision - Design - Dependency · Financial valuation - Flexibility $\cdot$ Risk - Scopes of action · Value contribution

\section{Introduction}

"Developing or managing a flexible infrastructure" (Gartner 2012, p. 7) still is a top target for IT-executives (Brancheau et al. 1996, p. 227; Gartner 2012, p. 7; Luftman et al. 2012, p. 200). Science recognized this, too, and broadly analyses the phenomena of flexibility of information systems (FIS). Foundations and influencing factors of FIS as well as the effects of FIS on the company's success are examined (Beimborn et al. 2006a; Byrd and Turner 2001; Chung et al. 2003; Duncan 1995; Jorfi et al. 2011; Moitra and Ganesh 2005; Oh et al. 2007). Thus, FIS may lead to competitive advantages (Byrd and Turner 2000; Duncan 1995) or can positively affect the quality of business processes (Beimborn et al. 2006b). The benefits of FIS are currently discussed along with architectural concepts such as service orientation and cloud computing. Both concepts are able to contribute to the flexibility of information systems (IS) significantly (Bartmann et al. 2011, p. 8; Becker et al. 2011, p. 10; Eymann and Winter 2008, p. 70; Leimeister et al. 2010, p. 7).

In a comprehensive way, FIS is defined as the ability of an IS to adapt purposefully to system or environmental changes within given limits (Bernandes and Hanna 2009, p. 41; Kumar and Stylianou 2014, p. 151; Voigt 2007, p. 600; Wagner et al. 2011, p. 811). It is enabled by the interaction of certain features of an IS, such as scalability, compatibility, or modularity (Table 1 shows an overview of all IS features previously identified via empirical 
Table 1 Overview and description of IS features enabling FIS (according to Chanopas et al. 2006, pp. 643, 645, 646)

\begin{tabular}{ll}
\hline IS feature & Description \\
\hline Compatibility & $\begin{array}{l}\text { The degree to which an IS can share any type of } \\
\text { information both inside and outside the } \\
\text { organization } \\
\text { The degree to which an IS can connect to others } \\
\text { both inside and outside the organization }\end{array}$ \\
Connectivity & $\begin{array}{l}\text { The degree to which an IS is available without } \\
\text { disruption }\end{array}$ \\
Continuity & $\begin{array}{l}\text { The degree to which an IS can be used with ease } \\
\text { Facility }\end{array}$ \\
IT personnel degree to which personnel working on and \\
competency & $\begin{array}{l}\text { with an IS possess relevant skills and experience } \\
\text { to effectively perform activities }\end{array}$ \\
Modernity & $\begin{array}{l}\text { The degree to which an IS is based on well- } \\
\text { known components/products and technological } \\
\text { trends }\end{array}$ \\
Modularity & $\begin{array}{l}\text { The degree to which an IS can be separated and } \\
\text { recombined to support new system development } \\
\text { The degree to which an IS can deliver }\end{array}$ \\
Rapidity & $\begin{array}{l}\text { information as soon as it is needed } \\
\text { The degree to which an IS can be scaled and } \\
\text { upgraded as well as expanded or downsized }\end{array}$ \\
\hline Scalability &
\end{tabular}

studies). Implemented ex ante, a combination of these features offer specific scopes of action during the lifetime of the IS. These scopes of action then can be used to adapt the IS to certain exogenous changes in a way that the objectives of the IS will continuously be achieved in the best possible way (Bernandes and Hanna 2009, p. 41; Chanopas et al. 2006, p. 646; Mandelbaum and Buzacott 1990, p. 17; Mellwig 1972, p. 726; Wagner et al. 2011, p. 811). A scalable and thus flexible online ordering system, for example, can be adjusted to fluctuating demand, and consequently costs of unused capacities or opportunity costs of lost demand can be avoided. In a dynamic environment characterized by frequent changes, FIS therefore is a key ability which should be developed and conserved (Byrd and Turner 2001, p. 41; Duncan 1995, p. 37; Veith et al. 2007, p. 1191).

FIS can contribute to business success, and for numerous IS investments it is "the key area of value added" (Hares and Royle 1994, p. 9). Simultaneously it carries significant costs (Gebauer and Schober 2006, p. 126; Golden and Powell 2000, p. 375). Decisions on the design of FIS (i.e., which IS features enabling FIS should be implemented ex ante and to what extent) must therefore be aligned to economic aspects (Allen and Boynton 1991; Becker et al. 2009, p. 10; Chanopas et al. 2006, p. 635; Veith et al. 2007, p. 1198). The basis of an economically informed decision on design alternatives of FIS is a theorybased, methodologically correct financial ex ante valuation of FIS (Irani and Love 2002, p. 79; Wehrmann et al. 2006, p. 235). ${ }^{1}$ Here, cash flows ${ }^{2}$ arising from the implementation of FIS and the adaptations enabled by its scopes of actions are aggregated using sound financial valuation approaches to determine the value contribution of FIS monetarily. This approach poses quite a challenge in practice, even though the high relevance of FIS and its financial valuation is recognized (Becker et al. 2009, p. 10; Kumar 2004, p. 12; Probst and Buhl 2012, p. 70; Trigeoris 1996, p 152). Problems arise mainly from the complexity of the flexibility construct in two areas: First, the ability to adapt to changes does not have a value in itself. Initially it is only a potential which can be utilized when addressable changes appear. Only then is an economic value added (Afflerbach et al. 2014; He et al. 2011, p. 3718). Suitable financial valuation approaches must be able to capture this and all other related characteristics of FIS driving its economic value. Second, when applying a suitable financial valuation approach, the required input, mainly in the form of cash flows associated with the specific IS during its lifetime (see Sect. 2 for details), is to be determined as completely and accurately as possible. This is a well-known and nonnegligible challenge, especially if scopes of action have to be considered (Buch and Dorfleitner 2007, p. 143; Franke and Hax 2009, p. 281; Perridon et al. 2012, pp. 81, 132; Schneider 1971, p. 834; Wehrmann et al. 2006, p. 239). Since FIS is enabled by the interaction of different IS features, the identification and estimation of all necessary input is connected to further difficulties, as it requires the examination of all corresponding IS features interacting in each particular application.

The sound evaluation of the use of IS in practice is a major target for BISE as an application oriented science (Heinzl et al. 2001, p. 225; Scheer 2009, p. 88; Wissenschaftliche Kommission Wirtschaftsinformatik 2011). Hence, one would expect that the extensive scientific literature on FIS (Chanopas et al. 2006; Kumar and Stylianou 2014; Wagner et al. 2011) supports the challenge of financial valuation by gathering necessary theoretical foundations as well as explaining and demonstrating their correct application in a comprehensive and structured way. The literature, however, shows deficits:

\footnotetext{
${ }^{1}$ In addition, qualitative, non-financial evaluation criteria can be considered (Hirschmeier 2005, p. 4; Kohli and Grover 2008, p. 33). The paper at hand focuses on the financial ex ante valuation of FIS as a specific challenge. Concerning other dimensions of business value (Schryen 2013) of FIS, cf., for example, Kumar and Stylianou (2014) and Wagner et al. (2011).

${ }^{2}$ Concerning the example of the flexible online ordering system, implementing scalability causes cash outflows. Cash inflows attributable to flexibility arise from both, avoided idle costs through scaling (when demand is low) and additionally processible jobs (when demand is high).
} 
Table 2 Examples of FIS descriptions found in the IS-literature (highlighting by the author)

\begin{tabular}{|c|c|}
\hline Publication & Description \\
\hline $\begin{array}{l}\text { Beimborn et al. (2006b, } \\
\text { p. 589) }\end{array}$ & $\begin{array}{l}\text { "[...] we define IT flexibility as the ability to renew IT competences to match changing business requirements } \\
\text { with little penalty in time, effort, cost or performance" }\end{array}$ \\
\hline $\begin{array}{l}\text { Byrd and Turner }(2000 \text {, } \\
\text { p. 172) }\end{array}$ & $\begin{array}{l}\text { "IT infrastructure flexibility is the ability to easily and readily diffuse or support a wide variety of hardware, } \\
\text { software, communications technologies, data, core applications, skills and competencies, commitments, and } \\
\text { values within the technical physical base and the human component of the existing IT infrastructure" }\end{array}$ \\
\hline $\begin{array}{l}\text { Cheung and Bagranoff (1991, } \\
\text { p. 36) }\end{array}$ & $\begin{array}{l}\text { "Four types of systems flexibilities are addressed: options to defer the system, to expand the system, to } \\
\text { downsize the system, and to redeploy the system for competing uses." }\end{array}$ \\
\hline Jacome $(2007$, p. 3) & $\begin{array}{l}\text { "We can define IS flexibility as the ability of the components that collect, process, store and output information } \\
\text { to adapt to changes, so that the new business tasks can adequately be performed in a continuous manner" }\end{array}$ \\
\hline $\operatorname{Kumar}(2004$, p. 12) & "[IT-] flexibility, the ability to quickly and economically adapt to changing business requirements $[\ldots] "$ \\
\hline $\begin{array}{l}\text { Latt and Altmann } \\
(2011, \text { p. 655) }\end{array}$ & $\begin{array}{l}\text { "Service flexibility is defined here as the possibility of users to adapt their business process according to their } \\
\text { needs" }\end{array}$ \\
\hline Nelson et al. (1997, p. 77) & $\begin{array}{l}\text { "[...] definition of technology flexibility: the ability to adapt to both incremental and revolutionary change in } \\
\text { the business or business process with minimal penalty to current time, effort, cost, or performance" }\end{array}$ \\
\hline Shaw et al. (2007, p. 92) & $\begin{array}{l}\text { "[...] business process flexibility: the ability to change organizational capabilities repeatable, economically and } \\
\text { in a timely way" }\end{array}$ \\
\hline
\end{tabular}

- Still there is no consistent understanding of the construct of FIS. Table 2 lists examples of different definitions and shows that a variety of non-uniform, varyingly precise, and limited definitions of FIS are common. Due to these different perspectives on FIS adopted within the literature, comprehensive theoretical considerations necessary for a sound valuation ${ }^{3}$ turn out to be quite difficult. This mainly concerns the identification of all characteristics of FIS which drive its economic value and which are crucial to identify suitable valuation approaches. The rising stream of literature regarding FIS analogous to a financial option (Benaroch 2002, p. 47; Cheung and Bagranoff 1991, p. 36; Fichman 2004, p. 133; Hilhorst and Smits 2004, p. 7; Panayi and Trigeoris 1998, p. 676) illustrates the need for a comprehensive understanding and aligned theoretical considerations. These papers adopt a very specific perspective on flexibility only and thus may mislead the reader to believe that flexibility can only be valuated based on option pricing theory.

- Comprehensive theoretical considerations and especially the demonstration of FIS valuation in certain applications which consider the different IS functions enabling FIS are limited. With regard to the challenges of determining all required input to apply the valuation approaches properly, the latter is of particular importance, as it can support practice when, for example, used as a blueprint or at least as a guideline. However, recent reviews show that the focus in the literature on FIS remains on the differentiation of flexibility, especially regarding similar or related constructs ("agility"

\footnotetext{
3 To facilitate readability, "valuation" or "value" here and in the following means "financial valuation" or "financial value".
}

and "responsiveness"), and on the identification of types and dimensions of flexibility (Bernandes and Hanna 2009; Kumar and Stylianou 2014). The few existing papers on FIS valuation note that this important issue is inadequately represented in literature (Schober and Gebauer 2011, p. 638)—a gap difficult to understand, as the complexity of FIS and the difficulties in its valuation are known and unchallenged.

Having these deficits in mind, this paper pursues two targets:

1. Supported by a broad literature basis from BISE and Finance, a comprehensive definition of FIS is introduced, theoretical foundations of a sound financial valuation of FIS are gathered and suitable financial valuation approaches are identified and presented.

2. On the basis of a structured review, the literature focusing the application of FIS valuation is summarized and analyzed concerning its theoretical foundation as well as the particular application scenario and the IS features examined.

Thus, in joining the theoretical basis and the application of FIS valuation, this paper gathers all necessary fundamentals for a sound valuation of FIS. This supports practice to reach economically informed decisions on FIS design. Moreover, it analyses the existing literature concerning FIS and reveals the need for further development within this part of BISE research.

The paper adapts the approach of a structure literature review to its targets (Fettke 2006, p. 260; Tranfield et al. 2003; Webster and Watson 2002): The problem to be investigated has been defined above. In Sect. 2, theoretical foundations are gathered and valuation approaches suitable for FIS are 
identified (Target 1). Based on these and the challenges associated with FIS valuation raised in the introduction, the framework to analyze the literature on FIS valuation is developed and the procedure of literature search and selection is outlined in Sect. 3. Following in Sect. 4, literature on the application of FIS valuation is analyzed (Target 2). The conclusion in Sect. 5 summarizes the findings of the paper focusing on the further needs of research drawn from the literature analysis.

\section{Theoretical Foundations of a Sound Financial Valuation of FIS}

To gather the theoretical foundations of a sound financial valuation of FIS, fundamental requirements for the valuation of IS are introduced and the characteristics of FIS driving its economic value are discussed using a comprehensive definition of FIS. Based on this, the approaches which are applicable for the valuation of FIS are identified and explained.

\subsection{Fundamental Requirements for IS Valuation}

IS are valuated to make economically informed decisions between design alternatives (Bannister and Remenyi 2000, p. 231). This valuation has to be conducted according to the principles of IT-Governance, which include value orientation and risk management as central guidelines (IT Governance Institute 2003, p. 26; Krcmar 2010, p. 288; Zimmermann 2008a, p. 358). From these guidelines fundamental requirements for the valuation of IS can be derived, which also have to be considered when assessing FIS (Häckel et al. 2011, p. 415; Wehrmann et al. 2006, p. 235; Zimmermann 2008b, p. 461) ${ }^{4}$ :

- Requirement 1 (value contribution): The valuation is based on the IS's value contribution to the company value, which is determined by all attributable (stochastic) cash flows during the lifetime of the IS.

- Requirement 2 (considering risk): In determining the value contribution, the risks associated with the IS have to be considered adequately. These appear as positive and negative deviations from the IS 's expected cash flows.

- Requirement 3 (considering dependencies): In determining the value contribution, intratemporal (related to one point in time) and intertemporal (related to different points in time) dependencies of stochastic cash flows of the IS have to be considered adequately.

\footnotetext{
4 These sources discuss a larger number and/or more restrictive requirements that take account of specific focuses than those presented in this paper. The requirements listed here present a comprehensive and general intersection in terms of a quantitative financial valuation.
}

By determining the value contribution and risk connected to an IS, design alternatives can be compared based on their economic effects on the company as a whole (Häckel et al. 2011, p. 414; Wehrmann et al. 2006, p. 236; Zimmermann 2008b, p. 464). If FIS is achieved, for example, by the modularization of an IS, the number of modules is a design parameter. When comparing two design alternatives, a higher number of modules increases the scopes of action and thus flexibility. However, this does not necessarily result in an economic advantage if associated cash flows and risks exceed the economic benefits drawn from flexibility.

Moreover, dependencies of the stochastic cash flows influence value contribution and risk significantly (Häckel et al. 2011, p. 415; Wehrmann et al. 2006, p. 235). There may be dependencies between particular cash flows of the valuated IS itself, but also dependencies on the cash flows of the company-wide IS landscape. Considering the modularized IS mentioned above, a decision about the number of modules can affect the requirements (and associated cash flows) concerning IT security (intratemporal). At the same time, the specification of a fixed number of modules may curtail the flexibility of business processes as a part of the existing IS environment and reduce future profits (intertemporal). Design alternatives therefore differ in value contribution and risk but also in the dependencies of their cash flows, which necessarily have to be considered (Häckel et al. 2011, p. 415).

\subsection{Comprehensive FIS Definition and FIS \\ Characteristics Driving its Economic Value}

Concerning the concept of flexibility, a variety of economically influenced definitions exists in various fields such as finance, organization, production, decision theory, and BISE (Voigt 2007). It is agreed upon that flexibility is a multidimensional and polymorphic construct and thus difficult to define (Evans 1991, p. 73; Sethi and Sethi 1990, p. 289; Suarez et al. 1995, p. 31). Because of this, a standardized and generally accepted understanding of flexibility with a uniform definition and a taxonomy for different fields of research does still not exist (Golden and Powell 2000, p. 373; Saleh 2009, p. 307; Voigt 2007, p. 605). Especially in the literature of BISE, a variety of diversely precise descriptions of FIS can be found, which are usually limited to particular elements of an IS ${ }^{5}$ (Byrd and Turner 2000, p. 172; Chanopas et al. 2006, p. 633; Jacome 2007, p. 3; Shaw et al. 2007, p. 92).

\footnotetext{
5 IS include " $[\mathrm{t}]$ he entire infrastructure, organization, personnel, and components for the collection, processing, storage, transmission, display, dissemination, and disposition of information" (ATIS 2013). These numerous elements of IS are usually organized on architectural layers (Aier and Winter 2009, p. 178; Buhl and Kaiser 2008, p. 47; Krcmar 1990, p. 399; Winter 2003, p. 94). A definition/description of flexibility, based only on single elements or individual layers of an IS must therefore be regarded as limited, especially since existing dependencies cannot be or are only partially accounted for in the analysis.
} 
Within this paper, FIS is comprehensively defined as an ex ante designed ability of an IS to adapt purposefully to system or environmental changes within given limits during its lifetime (Bernandes and Hanna 2009, p. 41; Voigt 2007 p. 600; Wagner et al. 2011, p. 811). This definition aims for the complete IS and does not limit itself to specific elements of the IS. The majority of literature from other disciplines use similar definitions of flexibility, especially when referring to (investment) decisions regarding an economically informed application of flexibility and the associated quantitative valuation or measurement (Mandelbaum and Buzacott 1990, p. 17; Mellwig 1972, p. 726; Voigt 2007, p. 606). Moreover, this definition follows a recent comprehensive literature study on IS flexibility, which summarizes FIS in an analogous definition (Wagner et al. 2011, p. 811). Thus, this comprehensive definition is suitable to derive the characteristics of FIS that drive its economic value.

The definition shows that FIS aims for exogenous changes. These generally lead to the fact that the objectives of an affected IS can no longer be achieved in the best possible way. Being adaptable, the IS can cope with opportunities and risks resulting from exogenous changes without having to be replaced completely before the end of its lifetime (Bernandes and Hanna 2009, p. 41; Perridon et al. 2012, p. 111; Saleh 2009, p. 307). This is achieved by scopes of action enabled by various IS features which have to be implemented ex ante (Bernandes and Hanna 2009, p. 41; Mandelbaum and Buzacott 1990, p. 17; Mellwig 1972, p. 726). When these scopes of action are in place, decisions on the design of an IS are not bound to the very time the IS is implemented. Rather, subsequent decisions during the lifetime of the IS are enabled within given limits and previous decisions can be revised, i.e., taken back or altered. (Gupta and Rosenhead 1968, pp. B-19; Marschak and Nelson 1962, p. 42; Perridon et al. 2012, p. 141). The scopes of action specify all possible subsequent decisions and thus the limits and the amount of cash necessary for adaptation to exogenous changes (Bernandes and Hanna 2009, p. 41; Saleh 2009, p. 307).

FIS therefore constitutes a financial value only if system or environmental changes occur during the lifetime of the IS, and if the scopes of action allow an adaptation to these particular changes. Summarized, the value of FIS depends on which system or environmental changes occur during the lifetime of the IS, which scopes of action are available, and to what extent these scopes of action enable adaptation to the changes. ${ }^{6}$ Furthermore, it is also connected with risk,

\footnotetext{
${ }^{6}$ Concerning the example of the flexible online ordering system again: a scalable IS can be adapted to a widely fluctuating demand. Modularization, however, does not allow an adaptation to this particular change. If the IS is able to scale but with certain restrictions, the adaptation is only partially possible.
}

as the available information on changes that may occur in the future is typically incomplete at the time of assessment (Laux 2005, p 105; Perridon et al. 2012, p. 108). Thus, all these characteristics of FIS which drive its economic value have to be captured by suitable valuation approaches.

\subsection{Financial Valuation Approaches Suitable} to Valuate FIS

The financial literature provides a variety of different theory-based valuation approaches (Franke and Hax 2009, p. 140; Perridon et al. 2012, p. 29). The decision tree approach (DTA) and the real option approach (ROA), both based on the net present value, are the only two valuation approaches that can capture all characteristics of FIS which drive its economic value and meet the fundamental requirements of a sound financial valuation of IS.

As a key financial valuation approach, the net present value (NPV) determines the value of an investment by summing up all its discounted future cash flows. The risk associated with these cash flows is taken into account by risk premiums on the required return or deductions for risk on payment surpluses (Buch and Dorfleitner 2007; Perridon et al. 2012, p. 52). This approach has prevailed in literature and practice, mainly because it is consistent with the generally accepted objective of a value-oriented management (Coenenberg and Schultze 2002; Coenenberg and Salfeld 2007, p. 3; Danielson et al. 2008, p. 62).

If scopes of action enable subsequent decisions during the lifetime of an investment, the NPV can be applied within the DTA (Hax and Laux 1972). Starting with the initial decision, this approach captures all possible random events subsequently along with their probabilities of occurrence and all following decisions within the branches of the so-called decision tree. Any combination of event and decision represented by one branch results in a specific level of cash flows. The value of the investment in total can then be determined by using the roll-back method. In this way, all combinations of a possible event (weighted with its probability of occurrence) and the subsequent decision are examined to identify the path of the decision tree where the expected NPV of the investment reaches its maximum (Franke and Hax 2009, p. 284; Perridon et al. 2012, p. 141).

The FIS characteristics driving its economic value are captured completely by the DTA: any system or environmental change is represented by an event in the decision tree. The scopes of action determine all possible decisions. The level of cash flows following a particular event/decision combination depends on the extent to which the available scopes of action makes it possible to adapt to the changes. The risk for the occurrence of exogenous changes is considered in the probabilities of occurrence of the particular events. 
To determine the value of FIS, the IS has to be valuated first assuming that no subsequent decisions are possible, even if external changes occur. Then the IS must be valuated again, taking into account the decisions enabled by the scopes of action. The difference between the two results equals the value of FIS (Merton and Perold 1993). To enable a decision between design alternatives of FIS for the same IS, the respective decision trees of the design alternatives are set up. These include the very same events, but differ in terms of possible decisions and therefore in terms of the cash flows of the event/decision combinations. The design alternative to be chosen (taking into account a possibly existing budget restriction) is the one expected to achieve the highest NPV (Perridon et al. 2012, p. 60).

Considering our previous example again: the number of accesses to the online ordering system, triggered by fluctuating demand, constitutes the risky event. If both possible design alternatives enable either a complete or a partial adaptation to the rise in access, they would allow different decisions leading to the very same event, resulting in different cash flows. The path with the highest expected NPV within each of the two different decision trees then determines the values and allows a financially sound decision between the two different design alternatives.

The ROA is the second approach available to deal with scopes of action within an investment. It considers the decisions possible during its lifetime in analogy to a financial option as so-called real options. The total value of the investment is determined from the NPV without scopes of action plus the value of all particular real options. To valuate a real option (and therefore to determine the value of flexibility), the valuation approach for financial options is used: At the time of valuation a self-financing portfolio duplicating the (real) option's cash flows is formed. It includes an asset traded on a market and a risk-free asset. The value of the (real) option is equal to the observable market price of the duplicating portfolio at the time of valuation (Perridon et al. 2012, pp. 146, 353; Trigeoris 1996).

Again, all FIS characteristics driving its economic value are captured completely: the scopes of action determine the particular real options to be valuated. The possible system or environmental changes and the associated risk are represented by the conditions of exercising the real options. The cash flows of the real option depend on the extent the available scopes of action enable adaptation to the changes. The procedure for determining the value of FIS corresponds to that of DTA. To decide between design alternatives, the respective NPV plus the value of each available real option has to be determined. Again, the design alternative to be chosen is the one expected to achieve the highest NPV considering possible budget restrictions (Perridon et al. 2012, p. 60).
In the familiar example, the opportunities enabled by scalability constitute a real option. The two design alternatives possess different real options because they allow a complete or only a partial adaptation to the increased number of accesses to the online ordering system. The different cash flows resulting from these real options have to be duplicated for each case and valuated.

Summing up, both valuation approaches are able to capture all FIS characteristics driving its economic value and they comply with the three fundamental requirements of IS valuation (see Table 3 for an overview): they use cash flows to determine the investment's value (Requirement 1) and consider possible risks (Requirement 2). Dependencies (Requirement 3) can be considered, for example, via stochastic dependency measures in DTA, and by bundling different options in ROA. $^{7}$ Both valuation approaches therefore allow a sound financial valuation of FIS and an economically informed decision on the design of FIS.

The fundamental difference between both valuation approaches is found in the assessment of risk. DTA considers the personal risk preference of the decision maker who usually is assumed to be risk-averse. Therefore, separate, i.e., state-dependent return rates are required to determine the NPV in the decision tree for each event/ decision combination. The ROA, however, relies on market prices observed for the duplication portfolio, which already include the risk of the underlying cash flows. It therefore valuates free from personal risk preferences (Perridon et al. 2012, pp. 148, 353). ${ }^{8}$

\section{Preliminary Work Necessary to Perform the Literature Review}

Having the theoretical foundations for a sound financial valuation of FIS in place, now the framework to review the literature on FIS valuation is presented along with the procedure of literature search and selection.

\footnotetext{
${ }^{7}$ See corresponding literature for further information. The scopes of action of FIS can be interpreted as special intertemporal dependencies, which are already captured by the application of DTA or ROA.

${ }^{8}$ As in all valuation approaches, there are critical questions about the applicability of DTA and ROA. With DTA particularly the statusdependent return rate poses a problem (Perridon et al. 2012, p. 148). This does not apply to ROA due to a valuation free of preferences. However, the necessity for a portfolio, continuously traded on the market, which perfectly duplicates the cash flows of the real option to be valued shows its limitations (Buch and Dorfleitner 2007, p. 142; Kruschwitz 2011, p. 420). These fundamental difficulties affect the value to be determined. See Hommel and Pritsch (1999, p. 130) or Perridon et al. (2012, p. 132) for procedures to handle these difficulties.
} 
Table 3 Overview of DTA and ROA concerning fundamental requirements for IS valuation and FIS characteristics driving its economic value

\begin{tabular}{|c|c|c|}
\hline & DTA & ROA \\
\hline \multicolumn{3}{|c|}{ Fundamental requirements for IS valuation } \\
\hline $\begin{array}{l}\text { Valuation on the basis of all } \\
\text { stochastic cash flows during the } \\
\text { lifetime of the IS }\end{array}$ & $\begin{array}{l}\text { Fulfilled: The net present value (NPV) } \\
\text { sums up all discounted future cash flows } \\
\text { of the IS at the time of valuation } \\
\text { considering the scopes of action within } \\
\text { the decision tree }\end{array}$ & $\begin{array}{l}\text { Fulfilled: The NPV sums up all discounted future cash flows } \\
\text { of the IS at the time of valuation without considering the } \\
\text { scopes of action. The value of cash flows of all real options } \\
\text { enabled by the scopes of action is determined by the market } \\
\text { prices of all corresponding duplication portfolios at the time } \\
\text { of valuation and added to the NPV }\end{array}$ \\
\hline $\begin{array}{l}\text { Consideration of risk as positive } \\
\text { and negative deviations from } \\
\text { expected cash flows }\end{array}$ & $\begin{array}{l}\text { Fulfilled: Calculating the NPV, risk can } \\
\text { be taken into account for by means of risk } \\
\text { premiums or deductions }\end{array}$ & $\begin{array}{l}\text { Fulfilled: For the NPV as described to the left. The risk of any } \\
\text { individual real option is reflected in the market price of the } \\
\text { duplication portfolio }\end{array}$ \\
\hline $\begin{array}{l}\text { Consideration of intra- und } \\
\text { intertemporal dependencies of } \\
\text { stochastic cash flows }\end{array}$ & $\begin{array}{l}\text { Fulfilled: Calculating the NPV, } \\
\text { dependencies can be considered, for } \\
\text { example, by stochastic dependency } \\
\text { measures }\end{array}$ & $\begin{array}{l}\text { Fulfilled: Dependencies can be considered, for example, by } \\
\text { bundling different options }\end{array}$ \\
\hline \multicolumn{3}{|c|}{ FIS characteristics driving its economic value } \\
\hline System or environmental changes & $\begin{array}{l}\text { Considered: By the events within the } \\
\text { decision tree }\end{array}$ & Considered: By the real options to be valuated \\
\hline Scopes of action & $\begin{array}{l}\text { Considered: By the decisions within the } \\
\text { decision tree }\end{array}$ & Considered: By the real options' exercising conditions \\
\hline $\begin{array}{l}\text { Extent of adaptations to changes } \\
\text { enabled by scopes of action }\end{array}$ & $\begin{array}{l}\text { Considered: By the cash flows following } \\
\text { from any event/decision combination }\end{array}$ & $\begin{array}{l}\text { Considered: By the performance of the asset held in the } \\
\text { duplication portfolio }\end{array}$ \\
\hline Risk associated with future changes & $\begin{array}{l}\text { Considered: By the events' probability of } \\
\text { occurrence }\end{array}$ & Considered: By the real options' exercising conditions \\
\hline
\end{tabular}

\subsection{Framework to Analyze Literature on FIS Valuation}

The theoretical foundations for FIS valuation illustrate its complexity. Their precise understanding and a comprehensive identification and assessment of all necessary input is required before applying the valuation approaches. For all financial valuation approaches, especially the cash flowsassociated with the specific IS during its lifetime-play a decisive role. Moreover, for both DTA and ROA, flexibility affect these cash flows in a substantial way. As already mentioned in the introduction, gathering all attributable and therefore required cash flows is difficult, even when an investment without flexibility is valuated. Considering scopes of action during the lifetime of the investment creates additional challenges. This is particularly true for FIS, since it is enabled by the interaction of numerous different IS features. The influence of all foreseeable system or environmental changes as well as the impact of all enabled adaptations on all cash flows have to be determined. Thus, in addition to theoretical considerations of FIS valuation, practice has a need for application-related literature which demonstrates a methodically correct valuation in particular applications. With regard to the different IS functions enabling FIS, it can support practice when, for example, used as a blueprint or at least a guideline.

Hence, to structure and to analyze the literature on FIS valuation according to Target 2 by examining its theoretical foundation and its particular application scenario, the following framework is applied: first, a structured overview of the relevant literature is given, focusing on the FIS characteristics driving its economic value as well as the valuation approach used. Then, an in-depth analysis of each paper is performed in order to analyze to what extent the fundamental requirements for IS valuation are followed as well as which IS features enabling scopes of action were focused on and therefore examined to gather the input (esp. cash flows) necessary for its valuation. In doing so, it can be shown whether the valuation of FIS within the literature was well founded, and the need for further development within this part of BISE research is revealed.

\subsection{Search for and Selection of Relevant Literature}

The definition of keywords is a crucial step to select all relevant papers as completely as possible from the wide range of literature covering a specific subject (Levy and Ellis 2006, p. 190). This is challenging due to the not yet fully developed understanding of FIS and the various features of an IS which enable flexibility. In consequence, a bundle of different terms was defined from central papers dealing with the construct of flexibility. This includes the terms agility and responsiveness, which describe two constructs related to flexibility (Bernandes and Hanna 2009, p. 31). And it includes all IS features, identified by empirical studies, which enable flexibility (Chanopas et al. 2006, p. 646; Byrd and Turner 2000, p. 192; Duncan 1995, 
Table 4 Literature search criteria

\begin{tabular}{|c|c|}
\hline Criterion & Characteristics \\
\hline \multirow{5}{*}{$\begin{array}{l}\text { Search } \\
\text { terms }\end{array}$} & Flexibility \\
\hline & Related constructs: agility, responsiveness \\
\hline & $\begin{array}{l}\text { IS features enabling flexibility: compatibility, connectivity, continuity, facility, it personnel competency, modernity, modularity, } \\
\text { rapidity, scalability }\end{array}$ \\
\hline & Terms related to the term flexibility: adaptability, corrigibility, hedging, liquidity, robustness, versatility \\
\hline & $\begin{array}{l}\text { Truncations have been used ("agil*" instead of "agility") in order to catch combinations such as "agile information systems". } \\
\text { Publications in German were searched using corresponding German terms. See Table } 8 \text { (in the online-appendix; available via } \\
\text { http://link.springer.com) for details. }\end{array}$ \\
\hline $\begin{array}{l}\text { Search } \\
\text { fields }\end{array}$ & Title, abstract, keywords \\
\hline \multirow[t]{3}{*}{ Journals } & $\begin{array}{l}\text { VHB Jourqual } 2 \text { (2008) Partial ranking "Wirtschaftsinformatik und Informationsmanagement" and "Electronic Commerce" } \\
\text { including up to category B, and the journals that were added to the relevant categories in Jourqual } 2.1 \text { of } 2011 \text { (those that the } \\
\text { author considers applicable in these partial rankings) }\end{array}$ \\
\hline & MIS journal ranking up to and including a score of 18,00 \\
\hline & Overall: 44 journals, listed in Table 8 (in the online-appendix) \\
\hline Conferences & $\begin{array}{l}\text { Americas Conference on Information Systems (AMCIS), European Conference on Information Systems (ECIS), International } \\
\text { Conference on Information Systems (ICIS), Hawaii International Conference on System Sciences (HICSS), Internationale Tagung } \\
\text { Wirtschaftsinformatik (WI) }\end{array}$ \\
\hline $\begin{array}{l}\text { Search } \\
\text { period }\end{array}$ & Publications from $2003 / 01$ to $2013 / 02$ \\
\hline
\end{tabular}

p. 52) as well as terms that have a close relationship to the term flexibility ${ }^{9}$ (Evans 1991, p. 75).

With regard to the sources of literature to be considered, recourse to top-tier publications of the respective disciplines has proven to be most effective (Webster and Watson 2002, p. xvi). For BISE, this would preferably include the VHB-Jourqual (Verband der Hochschullehrer für Betriebswirtschaft e. V. 2008) and the MIS Journal Ranking (Association for Information Systems 2013). These sources can be searched by using scientific databases, considering only results of journals which are listed in these rankings. Alternatively, a pre-selected and limited list of publications from the rankings can be searched. Taking into account the large number of different terms which are of common usage and cannot be further specified by adding terms such as "information system" (otherwise papers, which, for example, deal with flexibility in business processes, would not be found), the latter approach appears to be most useful. Otherwise, the list of results would require a subsequent manual selection of relevant literature which seems impossible to conduct with reasonable effort. A sufficiently large number of publications must then minimize the limitation caused by pre-

\footnotetext{
9 Evans (1991) discusses various terms, often used as a synonym for the term flexibility and aligned them in the three groups according to their various meaning. For this paper, the terms summarized in the group "Capacity for new situations" have been chosen, because this definition comes closest to the meaning of flexibility used here.
}

selecting. For this reason, 44 journals and 5 of the major international conferences were chosen.

As already noted in the introduction, modern architectural concepts currently boost the discussion on FIS. Working in a fast-evolving field, papers valuating FIS especially in contemporary scenarios should be focused on. Therefore, the period of search was specified to comprise roughly 10 years from January 2003 to February 2013. Table 4 outlines the literature search criteria.

The literature search was carried out in different databases which gave access to the archives of the respective journals or conferences (see online-appendix). The search terms were entered one at a time and all papers dealing with a quantitative financial analysis of IS were selected. In doing so, 16 papers (no duplicates) were identified and subsequently examined as to whether they deal with FIS and whether a valuation was made. As the understanding of FIS corresponding to the definition above was taken as a basis, four papers were excluded, such as Latt and Altmann (2011), who consider "service flexibility" as "the possibility for users to adapt their business process according to their needs", but do not include system or environmental changes in the quantitative analysis. Finally, twelve papers remained as relevant for this review.

\section{Literature Analysis}

To obtain an overview of the existing literature on FIS valuation, the relevant papers are summarized in Table 5, 
Table 5 Results of the literature analysis: understanding of FIS and valuation approaches found in the relevant papers

\begin{tabular}{|c|c|c|c|}
\hline Paper & Scopes of action and enabled adaptations & $\begin{array}{l}\text { System or environmental changes and } \\
\text { associated risk }\end{array}$ & $\begin{array}{l}\text { Valuation } \\
\text { approach }\end{array}$ \\
\hline $\begin{array}{l}\text { Bardhan et al. } \\
(2004 a, b)\end{array}$ & FIS enables the option to expand an IS/to add additional IS & $\begin{array}{l}\text { Customer acceptance and competitors' reactions } \\
\text { are risky and influence the cash flows of the } \\
\text { individual IS }\end{array}$ & ROA \\
\hline $\begin{array}{l}\text { Benaroch et al. } \\
(2007)\end{array}$ & $\begin{array}{l}\text { FIS enables the option to react to various defined changes } \\
\text { during the implementation of an IS }\end{array}$ & $\begin{array}{l}\text { Different risk factors identified in a case study } \\
\text { influence the risky cash flows of the IS }\end{array}$ & ROA \\
\hline $\begin{array}{l}\text { Braunwarth } \\
\text { and Ullrich } \\
(2010)\end{array}$ & $\begin{array}{l}\text { FIS enables an on-demand integration of service providers to } \\
\text { execute excess demand externally }\end{array}$ & $\begin{array}{l}\text { Stochastic demand leads to waiting times } \\
\text { influencing the risky cash flows of order } \\
\text { execution }\end{array}$ & DTA \\
\hline $\begin{array}{l}\text { Dolci et al. } \\
(2010)\end{array}$ & FIS enables the option to expand an IS/to add additional IS & $\begin{array}{l}\text { Different unspecified changes influence the } \\
\text { risky cash flows of the additional IS }\end{array}$ & ROA \\
\hline $\begin{array}{l}\text { Erdogmus } \\
(2005)\end{array}$ & $\begin{array}{l}\text { FIS enables the implementation of an IS in individually usable } \\
\text { sections and the termination of planned but not implemented } \\
\text { sections if necessary }\end{array}$ & $\begin{array}{l}\text { Each section changes the unspecified risks of } \\
\text { cash flows associated with planned but not } \\
\text { implemented sections }\end{array}$ & DTA \\
\hline Ilk et al. (2010) & $\begin{array}{l}\text { FIS enables the option to expand an IS/to add additional IS, to } \\
\text { postpone their implementation, and to put them to different } \\
\text { uses }\end{array}$ & $\begin{array}{l}\text { Different unspecified changes influence the risky } \\
\text { cash flows of the additional IS }\end{array}$ & ROA \\
\hline Kumar (2004) & FIS enables an IS to adapt to changes & $\begin{array}{l}\text { Different changes outlined by unspecified } \\
\text { examples influence the stochastic and thus risky } \\
\text { value of the IS }\end{array}$ & DTA \\
\hline $\begin{array}{l}\text { Probst and } \\
\text { Buhl (2012) }\end{array}$ & $\begin{array}{l}\text { FIS enables the combination of IS from different vendors to a } \\
\text { portfolio within a given period and with multiple decisions }\end{array}$ & $\begin{array}{l}\text { Usage and availability of the individual IS are } \\
\text { risky and influence the cash flows of the } \\
\text { portfolio }\end{array}$ & DTA \\
\hline $\begin{array}{l}\text { Schober and } \\
\text { Gebauer } \\
(2009,2011)\end{array}$ & $\begin{array}{l}\text { FIS enables an IS to adapt to changing requirements and to } \\
\text { expand its functionality accordingly }\end{array}$ & $\begin{array}{l}\text { Requirements that are not determined in advance } \\
\text { influence the thus risky cash flows of the IS }\end{array}$ & $\begin{array}{l}\text { DTA } \\
\text { and ROA }\end{array}$ \\
\hline $\begin{array}{l}\text { Sing et al. } \\
(2004)\end{array}$ & $\begin{array}{l}\text { FIS enables the option to change the vendor of an IS or the IS } \\
\text { itself in more frequent intervals by leasing the IS instead of } \\
\text { operating it internally }\end{array}$ & $\begin{array}{l}\text { Vendors and their available IS are continuously } \\
\text { developed and influence their risky cash flows }\end{array}$ & ROA \\
\hline
\end{tabular}

structured according to the characteristics of FIS which drive its economic value and to the valuation approach used.

A comparison of the different understanding of FIS reflected in the scopes of action and the enabled adaptations to exogenous changes considered within the relevant papers shows the diversity of the FIS construct and its various applications. Regarding the fundamental orientation of these papers, two priorities stick out: Dolci et al. (2010), Erdogmus (2005), Ilk et al. (2010) and Kumar (2004) examine the valuation of FIS conceptually. They present scopes of action and their impact on the cash flows of the respective IS, formulated in a rather general way, along with matching valuation approaches. Using examples, the application of the valuation approaches is demonstrated and the advantage over non-flexible IS is illustrated. Hence, these papers focus on demonstrating the suitability of the used valuation approaches to access the value of FIS. The eight remaining papers, however, assess specific applications by examining FIS design alternatives that enable specific scopes of action. Compared to the conceptually driven papers, specific exogenous changes and their impact on the cash flows of the respective IS are described in detail. Thus, the interaction of exogenous changes and the adaptations enabled by the scopes of action are shown clearly along with the difficulties and solutions to gather all necessary input for valuation in a particular application.

Both DTA and ROA are used equally within the set of relevant papers. The application of ROA is always immediately apparent. In all other papers, the proposed procedure for valuation corresponds to the application of the DTA, even though this is not mentioned explicitly or a variation of the ideal-typical application described above is respectively applied.

For the detailed analysis announced within the framework outlined above, all papers were examined individually. First, three questions were formulated to analyze to what extent the fundamental requirements for IS valuation are satisfied. Table 6 summarizes these questions along with the results of the analysis. It comes clear that all papers valuate FIS based on the cash flows attributable to flexibility during the lifetime of the IS. They also consider risk in form of deviations from the expected cash flows. Hence, the first two requirements stated above are fulfilled. 
Table 6 Results of the literature analysis: consideration of fundamental requirements for IS valuation within the relevant papers

\begin{tabular}{|c|c|c|c|}
\hline Paper & $\begin{array}{l}\text { Requirement 1: Is FIS valuated } \\
\text { based on its value contribution } \\
\text { determined by all attributable } \\
\text { cash flows during the lifetime } \\
\text { of the IS? }\end{array}$ & $\begin{array}{l}\text { Requirement } 2 \text { : Is risk } \\
\text { determined by deviations } \\
\text { from all attributable } \\
\text { expected cash flows } \\
\text { considered? }\end{array}$ & $\begin{array}{l}\text { Requirement 3: Are dependencies of } \\
\text { all attributable cash flows considered } \\
\text { that exceed the dependencies incurred } \\
\text { by the scopes of action? }\end{array}$ \\
\hline Bardhan et al. (2004a, b) & Yes & Yes & No \\
\hline Benaroch et al. (2007) & Yes & Yes & Yes \\
\hline Braunwarth and Ullrich (2010) & Yes & Yes & No \\
\hline Dolci et al. (2010) & Yes & Yes & No \\
\hline Erdogmus (2005) & Yes & Yes & No \\
\hline Ilk et al. (2010) & Yes & Yes & No \\
\hline Kumar (2004) & Yes & Yes & No \\
\hline Probst and Buhl (2012) & Yes & Yes & Yes \\
\hline Schober and Gebauer $(2009,2011)$ & Yes & Yes & No \\
\hline Sing et al. (2004) & Yes & Yes & Yes \\
\hline
\end{tabular}

Table 7 Results of the literature analysis: examined IS features enabling scopes of action

\begin{tabular}{|c|c|c|}
\hline Paper & Found with search term & $\begin{array}{l}\text { IS features enabling scopes of action considered within the papers } \\
\text { (an asterisk* denotes features mentioned explicitly in the paper's text) }\end{array}$ \\
\hline Bardhan et al. (2004a, b) & Flexibility & Scalability \\
\hline Benaroch et al. (2007) & Flexibility & Modularity, scalability \\
\hline Braunwarth and Ullrich (2010) & Flexibility & Compatibility, connectivity*, rapidity \\
\hline Dolci et al. (2010) & Flexibility & Scalability \\
\hline Erdogmus (2005) & Flexibility & Scalability \\
\hline Ilk et al. (2010) & Flexibility, agility & Modularity, scalability \\
\hline Kumar (2004) & Flexibility, connectivity & $\begin{array}{l}\text { Due to the conceptual nature of the study, an assignment of IS features } \\
\text { is not reasonable (cf. statements within the text). }\end{array}$ \\
\hline Probst and Buhl (2012) & Flexibility & Continuity, modularity* \\
\hline Schober and Gebauer $(2009,2011)$ & Flexibility & Scalability \\
\hline Sing et al. (2004) & Flexibility & $\begin{array}{l}\text { None of the characteristics identified so far can be assigned } \\
\text { (cf. statements within the text). }\end{array}$ \\
\hline
\end{tabular}

Dependencies, however, going beyond the necessarily considered dependencies caused by the scopes of action, are taken into consideration explicitly only by Benaroch et al. (2007), Probst and Buhl (2012), and Sing et al. (2004). All other papers valuate FIS assuming that the necessary decisions have no influence on any other cash flow associated with the particular IS or on any cash flows associated with other IS within the company's IS portfolio. Thus, they are neglecting important factors influencing the value of FIS.

For the second detailed analysis, the papers were examined concerning the IS features enabling scopes of action in their particular application. All papers were checked in detail as to which of the IS features, as listed in the introduction, are considered. Table 7 summarizes the results.

None of the papers directly refer to studies concerned with those features of an IS which initially enable the scopes of action. Hence, assigning the IS features considered within the papers was performed indirectly according to the scopes of action described in the particular paper. If relevant IS features were mentioned, even if there was no reference to the literature, the entry in Table 7 was marked with an asterisk (*). In two papers a mapping of IS features did not make sense or was not possible: Kumar (2004) mentions connectivity as an example of one of the known IS features, but considers the enabled adaptations only conceptually and abstracts from concrete characteristics. Hence, assigning this IS feature is not useful for the analysis within this review that aims to identify literature examining the valuation of FIS in detailed application scenarios. Sing et al. (2004) examines a particular scope of action that matches none of the known IS features enabling FIS.

Overall, the results of this second in-depth analysis show that the findings of empirical research on FIS concerning the IS features enabling scopes of action have not found 
their way into the literature on FIS valuation yet. Even though some of the IS features are found within the relevant papers, no (systematic) attention is paid to these central design parameters of FIS. This is surprising, as the connection to particular IS features, which enable scopes of action during the lifetime of an IS and thus build the fundamental cause FIS is reducible to, might help and simplify gathering all necessary input required for valuation by relying on the accumulated knowledge found within corresponding streams of BISE literature. Moreover, it is revealed that, contrary to the needs of practice, the literature on FIS valuation does not provide a structured and comprehensive approach to examine all interacting IS features enabling FIS in detailed application scenarios.

\section{Conclusion}

This paper deals with the state of research regarding the financial valuation of flexibility of information systems. It is founded on a comprehensive definition of FIS as the ability of an IS to adapt purposefully to system or environmental changes within given limits. Two targets are pursued: first, the theoretical foundations of a sound financial valuation of FIS are gathered and suitable financial valuation approaches are identified. Second, based on a structured review, the literature focusing on the application of FIS valuation in different specific scenarios is analyzed. Working with theoretical as well as with application-oriented literature of BISE and Finance, the following insights are gained:

- The value of FIS depends on the extent to which adaptations to exogenous changes are made possible by the scopes of action during the lifetime of an IS enabled by different IS features implemented ex ante. There are two theory-based approaches which are suitable for the financial valuation of FIS: the decision tree approach and the real option approach both comply with the three fundamental requirements for IS valuation and capture all FIS characteristics that drive its economic value. However, the application of these approaches is not trivial. It requires a thorough understanding of the approaches and a comprehensive identification and assessment of the required input to gain reliable results. Especially the impact of all FIS-enabled adaptations to system or environmental changes on all cash flows of the specific IS over its lifetime has to be determined.

- Collecting all attributable cash flows and the corresponding impact of FIS is difficult. As particular IS features build the fundamental cause FIS is reducible to, they play a key role. Application-related literature, demonstrating a methodically correct valuation with regard to these IS functions in particular applications, can support practice when, for example, used as a blueprint or a guideline. Unfortunately, the amount of corresponding literature is surprisingly small. Within only twelve papers different applications of FIS were examined concerning their financial value assessed by decision tree analysis or real option analysis, respectively.

- The existing literature on FIS valuation shows weak spots in two aspects: Dependencies, going beyond the necessarily considered dependencies caused by the scopes of action are mostly not taken into account. Eight out of twelve papers valuate FIS assuming that the necessary decisions have no influence on any other cash flow associated with the particular IS or on any cash flows associated with other IS within the company's IS portfolio. Thus, they are neglecting important factors relevant for the value of FIS. Further research must pay more attention to important dependencies, in order to avoid incorrect values leading to errant decisions. Furthermore, no systematic attention is paid to the findings of empirical research on FIS concerning the IS features enabling scopes of action. Contrary to the needs of practice, the literature on FIS valuation does not provide a structured and comprehensive approach to examine all interacting IS features enabling flexibility in detailed application scenarios. For this purpose, additional research is required to demonstrate a methodologically correct valuation for all these IS features.

The financial valuation of FIS is of major importance to make economically informed decisions on investments in FIS or on design alternatives of FIS. The results gained within this paper empowers practice with essential foundations to determine the financial value of FIS. In addition, it reveals the need for further development within this stream of BISE research.

\section{References}

Afflerbach P, Kastner G, Krause F, Roeglinger M (2014) The business value of process flexibility - an optimization model and its application in the service industry. Bus Inf Syst Eng 6(3):203-214

Aier S, Winter R (2009) Virtual decoupling for IT/business alignment - Conceptual foundations, architecture design and implementation example. Bus Inf Syst Eng 1(2):150-163

Allen BR, Boynton AC (1991) Information architecture: in search of efficient flexibility. MIS Q 15(4):435-445

Association for Information Systems (2013) MIS journal ranking. http://ais.affiniscape.com/displaycommon.cfm?an=1\&subarticlenbr= 432. Accessed 2 April 2013

ATIS (2013) ATIS telecom glossary. http://www.atis.org/glossary/ definition.aspx?id=4529. Accessed 2 April 2013 
Bannister F, Remenyi D (2000) Acts of faith: instinct, value and IT investment decisions. J Inf Technol 15(3):231-241

Bardhan I, Bagchi S, Sougstad R (2004a) Prioritizing a portfolio of information technology investment projects. Manag Inf Syst 21(2):33-60

Bardhan I, Bagchi S, Sougstad R (2004b) A real options approach for prioritization of a portfolio of information technology projects: a case study of a utility company. In: Proc 37th Hawaii internat conf syst sci. Maui, pp 1-11

Bartmann D, Bodendorf F, Ferstl OK, Sinz EJ (2011) Merkmale, Systemarchitekturen und Management hochflexibler Geschäftsprozesse. In: Sinz EJ, Bartmann D, Bodendorf F, Ferstl OK (eds) Dienstorientierte IT-Systeme für hochflexible Geschäftsprozesse. University of Bamberg Press, Bamberg

Becker A, Buxmann P, Widjaja T (2009) Value potential and challenges of service-oriented architectures - a user and vendor perspective. In: Proc 17th Eur conf inf syst. Verona, pp 1-12

Becker J, Beverungen D, Knackstedt R, Matzner M, Müller O, Pöppelbuß J (2011) Flexible Informationssystem-Architekturen für hybride Wertschöpfungsnetzwerke (FlexNet). Arbeitsbericht Nr. 130 des Instituts für Wirtschaftsinformatik der Universität Münster. http://www.wi.uni-muenster.de/institut/forschen/ arbeitsberichte.php. Accessed 2 April 2013

Beimborn D, Franke J, Wagner H, Weitzel T (2006a) The impact of outsourcing on IT business alignment and IT flexibility: a survey in the German banking industry. In: Proc 12th Am conf inf syst. Acapulco, pp 3189-3198

Beimborn D, Franke J, Wagner H, Weitzel T (2006b) Strategy matters: the role of strategy type for IT business value. In: Proc 12th Am conf inf syst. Acapulco, pp 588-597

Benaroch M (2002) Managing information technology investment risk: a real options perspective. Manag Inf Syst 19(2):43-84

Benaroch M, Jeffery M, Kauffmann RJ, Shah S (2007) Option-based risk management: a field study of sequential information technology investment decisions. J Manag Inf Syst 24(2):103-140

Bernandes ES, Hanna MD (2009) A theoretical review of flexibility, agility and responsiveness in the operations management literature. Int J Op Prod Manag 29(1):30-53

Brancheau JC, Janz BD, Wetherbe JC (1996) Key issues in information systems management: 1994-95 SIM Delphi results. MIS Q 20(2):225-242

Braunwarth K, Ullrich C (2010) Valuating business process flexibility achieved through an alternative execution path. In: Proc 18th Eur conf inf syst. Pretoria, pp 1-13

Buch A, Dorfleitner G (2007) Ein Vergleich der Sicherheitsäquivalentmethode und der Risikoanalyse als Methoden zur Bewertung risikobehafteter Zahlungsströme. Z Betriebswirtschaft 77(2):141-170

Buhl HU, Kaiser M (2008) Herausforderungen und Gestaltungschancen aufgrund von MiFID und EU-Vermittlerrichtlinie in der Kundenberatung. Z Bankrecht Bankwirtschaft 20(1):43-51

Byrd TA, Turner DE (2000) Measuring the flexibility of information technology infrastructure: exploratory analysis of a construct. Manag Inf Syst 17(1):167-208

Byrd TA, Turner DE (2001) An exploratory examination of the relationship between flexible IT infrastructure and competitive advantage. Inf Manag 39(1):41-52

Chanopas A, Krairit D, Khang DB (2006) Managing information technology infrastructure: a new flexibility framework. Manag Res News 29(10):632-651

Cheung JK, Bagranoff NA (1991) Assessing intangible costs and benefits in the systems decision via option pricing theory. J Inf Syst 5(1):36-47
Chung SH, Rainer RKJ, Lewis BR (2003) The impact of information technology infrastructure flexibility on strategic alignment and applications implementation. Commun AIS 11(1):191-206

Coenenberg AG, Salfeld R (2007) Wertorientierte Unternehmensführung: Vom Strategieentwurf zur Implementierung, 2nd edn. Schäffer-Poeschel, Stuttgart

Coenenberg AG, Schultze W (2002) Unternehmensbewertung: Konzeptionen und Perspektiven. Betriebswirtschaft 62(6):597-621

Danielson MG, Heck JL, Shaffer DR (2008) Shareholder theory how opponents and proponents both get it wrong. J Appl Financ 18(2):62-66

Dolci PC, Macada ACG, Becker JL (2010) IT investment management using the real options and portfolio management approaches. In: Proc 16th Am conf inf syst. Lima, pp 1--10

Duncan NB (1995) Capturing flexibility of information technology infrastructure: a study of resource characteristics and their measure. Manag Inf Syst 12(2):37-57

Erdogmus H (2005) The economic impact of learning and flexibility on process decisions. IEEE Softw 22(6):76-83

Evans JS (1991) Strategic flexibility for high technology manoeuvres: a conceptual framework. J Manag Stud 28(1):69-89

Eymann T, Winter R (2008) SOA - Ein neues Paradigma der Gestaltung verteilter Informationssysteme? WIRTSCHAFTSINFORMATIK 50(1):70-76

Fettke P (2006) State-of-the-Art des State-of-the-Art: Eine Untersuchung der Forschungsmethode "Review" innerhalb der Wirtschaftsinformatik. WIRTSCHAFTSINFORMATIK 48(4):257-266

Fichman RG (2004) Real options and IT platform adoption: implications for theory and practice. Inf Syst Res 15(2):132-154

Franke G, Hax H (2009) Finanzwirtschaft des Unternehmens und Kapitalmarkt, 6th edn. Springer, Heidelberg

Gartner (2012) Amplifying the enterprise: the 2012 CIO agenda

Gebauer J, Schober F (2006) Information system flexibility and the cost efficiency of business processes. J Assoc Inf Syst 7(3):122-147

Golden W, Powell P (2000) Towards a definition of flexibility: in search of the Holy Grail? Omega 28(4):373-384

Gupta S, Rosenhead J (1968) Robustness in sequential investment decisions. Manag Sci 15(2):B18-B29

Häckel B, Hänsch F, Isakovic V (2011) Langfristige versus periodische IT - Investitionsbewertung im Rahmen einer wertorientierten Unternehmensführung. In: Bernstein A, Schwabe G (eds) Proc 10th internat conf Wirtschaftsinformatik. Zürich, pp 414-423

Hares JS, Royle D (1994) Measuring the value of information technology. Wiley, Chichester

Hax H, Laux H (1972) Flexible Planung-Verfahrensregeln und Entscheidungsmodelle für die Planung bei Ungewißheit. $\mathrm{Z}$ betriebswirtschaftliche Forschung 24:318-340

He P, Xu X, Hua Z (2011) A new method for guiding process flexibility investment: flexibility fit index. Int $\mathrm{J}$ Prod Res 50(14):3718-3737

Heinzl A, König W, Hack J (2001) Erkenntnisziele der Wirtschaftsinformatik in den nächsten drei und zehn Jahren. WIRTSCHAFTSINFORMATIK 43(3):223-233

Hilhorst C, Smits M (2004) A resource based and real options perspective on IT infrastructure investments aiming for strategic flexibility. In: Proc 12th Eur conf inf syst. Turku, pp 1-12

Hirschmeier M (2005) Wirtschaftlichkeitsanalysen für IT-Investitionen. WiKu, Köln

Hommel U, Pritsch G (1999) Marktorientierte Investitionsbewertung mit dem Realoptionsansatz: Ein Implementierungsleitfaden für die Praxis. Finanzmarkt Portf Manag 13(2):121-144 
Ilk N, Goes P, Zhao JL (2010) A framework to support serviceoriented architecture investment decisions. In: Proc 31st internat conf inf syst. St. Louis, pp 1-15

Irani Z, Love PED (2002) Developing a frame of reference for ex-ante IT/IS investment evaluation. Eur J Inf Sys 11(1):74-82

IT Governance Institute (2003) IT Governance für Geschäftsführer und Vorstände. http://www.itgi.org/Template_ITGI64fc.pdf?Sec tion=About_IT_Governance1\&Template=/ContentManagement/ ContentDisplay.cfm\&ContentID=14529. Accessed 2 April 2013

Jacome L (2007) Evaluating information systems flexibility: a research approach to build a framework. In: Proc 13th Am conf inf syst. Keystone, pp 1-10

Jorfi S, Nor KM, Najjar L, Jorfi H (2011) The impact of IT flexibility on strategic alignment. Int J Bus Manag 6(8):264-270

Kohli R, Grover V (2008) Business value of IT: an essay on expanding research directions to keep up with the times. J Assoc Inf Syst 9(1):23-39

Krcmar H (1990) Bedeutung und Ziele von InformationssystemArchitekturen. WIRTSCHAFTSINFORMATIK 32(5):395-402

Krcmar H (2010) Informations management, 5th edn. Springer, Heidelberg

Kruschwitz L (2011) Investitionsrechnung, 13th edn. Oldenbourg, München

Kumar RL (2004) A framework for assessing the business value of information technology infrastructures. Manag Inf Syst 21(2):11-32

Kumar RL, Stylianou AC (2014) A process model for analyzing and managing flexibility in information systems. Eur J Inf Syst 23:151-184

Latt KS, Altmann J (2011) A cost-benefit-cased analytical model for finding the optimal offering of software services. In: Bernstein A, Schwabe G (eds) Proc 10th internat conf Wirtschaftsinformatik. Zürich, pp 655-664

Laux H (2005) Entscheidungstheorie, 6th edn. Springer, Heidelberg

Leimeister S, Riedl C, Böhm M, Krcmar H (2010) The business perspective of cloud computing: Actors, roles, and value networks. In: Proc 18th Eur conf inf syst. Pretoria, pp 1-12

Levy Y, Ellis TJ (2006) A systems approach to conduct an effective literature review in support of information systems research. Inf Sci J 9:181-212

Luftman J, Zadeh HS, Derksen B, Santana M, Rigoni EH, Huang Z (2012) Key information technology and management issues 2011-2012: an international study. J Inf Technol 27(3):198-212

Mandelbaum M, Buzacott J (1990) Flexibility and decision making. Eur J Operat Res 44(1):17-27

Marschak T, Nelson R (1962) Flexibility, uncertainty, and economic theory. Metroeconomica 14(1-3):42-58

Mellwig W (1972) Flexibilität als Aspekt unternehmerischen Handelns. Z betriebswirtschaftliche Forschung 24(11):724-744

Merton RC, Perold A (1993) Theory of risk capital in financial firms. J Appl Corp Financ 6(3):16-32

Moitra D, Ganesh J (2005) Web services and flexible business processes: towards the adaptive enterprise. Inf Manag 42(7):921-933

Nelson KM, Nelson HJ, Ghods M (1997) Technology flexibility: conceptualization, validation, and measurement. In: Proc 30th Hawaii internat conf syst sci. Maui, pp 76-87

Oh L, Teo H, Leong Y, Ravichandran T (2007) Service-oriented architecture and organizational integration: an empirical study of IT-enabled sustained competitive advantage. In: Proc 28th internat conf inf syst. Montreal, pp 1-17

Panayi S, Trigeoris L (1998) Multi-stage real options: the cases of information technology infrastructure and international bank expansion. Q Rev Econ Financ 38:675-692

Perridon L, Steiner M, Rathgeber A (2012) Finanzwirtschaft der Unternehmung, 16th edn. Vahlen, München
Probst F, Buhl HU (2012) Supplier portfolio management for IT services considering diversification effects. Bus Inf Syst Eng $5(2): 71-83$

Saleh JH (2009) Flexibility: a multi-disciplinary literature review and a research agenda for designing flexible engineering systems. Eng Des 20(3):307-323

Scheer A (2009) Business and information systems engineering links science with entrepreneurship. Bus Inf Syst Eng 1(1):75-80

Schneider D (1971) Flexible Planung als Lösung der Entscheidungsprobleme unter Ungewißheit? $\mathrm{Z}$ betriebswirtschaftliche Forschung 23(7):831-851

Schober F, Gebauer J (2009) How much to spend on flexibility? Determining the value of information system flexibility. In: Proc 15th Am conf inf syst. San Francisco, pp 1-13

Schober F, Gebauer J (2011) How much to spend on flexibility? Determining the value of information system flexibility. Decis Support Syst 51(3):638-647

Schryen G (2013) Revisiting IS business value research: what we already know, what we still need to know, and how we can get there. Eur J Inf Syst 22(2):139-169

Sethi AK, Sethi SP (1990) Flexibility in manufacturing: a survey. Flex Servic Manuf J 2(4):289-328

Shaw DR, Holland CP, Kawalek P, Snowdon B, Warboys B (2007) Elements of a business process management system: theory and practice. Bus Process Manag J 13(1):91-107

Sing C, Shelor R, Jiang J, Klein G (2004) Rental software valuation in IT investment decisions. Decis Support Syst 38(1):115-130

Suarez F, Cusumano M, Fine C (1995) An empirical study of flexibility in manufacturing. Sloan Manag Rev 37(1):25-32

Tranfield DR, Denyer D, Smart P (2003) Towards a methodology for developing evidence-informed management knowledge by means of systematic review. Br J Manag 14:207-222

Trigeoris L (1996) Real options: management flexibility and strategy in resource allocation. MIT Press, Cambridge

Veith V, Leimeister JM, Krcmar H (2007) Towards value-based management of flexible IT environments. In: Proc 15th Eur conf inf syst. St. Gallen, pp 1190-1201

Verband der Hochschullehrer für Betriebswirtschaft e.V. (2008) VHB-JOURQUAL 2. http://vhbonline.org/service/jourqual/jq2/. Accessed 2 April 2013

Voigt K (2007) Zeit und Zeitgeist in der Betriebswirtschaftslehre dargestellt am Beispiel der betriebswirtschaftlichen Flexibilitätsdiskussion. Z Betriebswirtschaft 77(6):595-613

Wagner D, Suchan C, Leunig B, Frank J (2011) Towards the analysis of information systems flexibility: proposition of a method. In: Proc 10th internat conf Wirtschaftsinformatik. Zürich, pp 808-817

Webster J, Watson RT (2002) Analyzing the past to prepare for the future: writing a literature review. MIS Q 26(2):xiii-xxiii

Wehrmann A, Heinrich B, Seifert F (2006) Quantitatives ITPortfoliomanagement: Risiken von IT-Investitionen wertorientiert steuern. WIRTSCHAFTSINFORMATIK 48(4):234-245

Winter R (2003) Modelle, Techniken und Werkzeuge im Business Engineering. In: Österle H, Winter R (eds) Business Engineering. Auf dem Weg zum Unternehmen des Informationszeitalters, 2nd edn. Springer, Heidelberg, pp 87-118

Wissenschaftliche Kommission Wirtschaftsinformatik (2011) Profil der Wirtschaftsinformatik. In: Kurbel K, Becker J, Gronau N, Sinz E, Suhl L (eds) Enzyklopädie der Wirtschaftsinformatik, 5 th edn. Oldenbourg, München

Zimmermann S (2008a) Governance im IT-Portfoliomanagement Ein Ansatz zur Berücksichtigung von Strategic Alignment bei der Bewertung von IT. WIRTSCHAFTSINFORMATIK 50(5):357-365

Zimmermann S (2008b) IT-Portfoliomanagement - Ein Konzept zur Bewertung und Gestaltung von IT. Inf Spektrum 31(5):460-468 